\title{
What Factors Do Motivate Employees at the Workplace? Evidence from Service Organizations
}

\author{
Md. Atikur RAHAMAN ${ }^{1}$, Md. Julfikar ALI' ${ }^{2}$, M Atif WAFIK', \\ Zahidur Rahman MAMOON ${ }^{4}$, Md. Monwarul ISLAM ${ }^{5}$
}

Received: September 01, 2020 Revised: October 26, 2020 Accepted: November 05, 2020

\begin{abstract}
Work motivation is critical for ensuring sustainability of any business firm. Motivated personnel essentially helps an organization achieve its organizational goal and objective. Hence, it has become an essential duty for business managers and management committees to identify the motivating factors that would strongly affect their employees. The purpose of the current research is to identify which are the factors that motivate service employees most at their workplace in Bangladesh. The study has used survey questionnaires to collect data from service employees. Convenience sampling is used for data collection. A total of 240 questionnaires were distributed and 183 completed questionnaires were returned (response rate: $77 \%$ ). The study used purposeful motivating factors, which are ranked (from 1 to 10 ) by the service employees according to the significance of the factors. Mean value is applied to determine the most crucial motivating factor, where the factor with lowest mean value is considered as the highest significant motivating factor. Results reveal that job certainty, career growth and advancement opportunity, and quality working environment have been the most crucial and influential motivating factors for the service employees. The study adequately underlines the necessity of motivational factors and provides some guidelines to keep employees motivated.
\end{abstract}

Keywords: Motivation, Service Organization, Employees, Job Certainty, Bangladesh

JEL Classification Code: A20, M12, M51

\section{Introduction}

Motivation has been the internal control system for affecting individual actions, which is built on the informative consciousness that make individuals act. Generally, action and

${ }^{1}$ First Author and Corresponding Author. Associate Professor, School of Economics \& Management, Jiujiang University, Jiangxi, China [Postal Address: 551 Qianjin Donglu, Jiujiang, Jiangxi, 332000, P.R. China] Email: atik@jju.edu.cn

${ }^{2}$ Associate Professor, Department of Business Administration, The International University of Scholars (IUS), Bangladesh.

Email: jalidhaka2020@gmail.com

${ }^{3}$ Lecturer, BBA Coordinator, The International University of Scholars, Bangladesh. Email: atikwafik@gmail.com

${ }^{4}$ Assistant Professor, Department of Business Administration, Eminence College Uttara, Dhaka, Bangladesh. Email: zrm347@gmail.com

${ }^{5}$ Additional Director, Student Affairs \& Digital Marketing, Northern

University Bangladesh. Email: rebelmonwardigital@gmail.com

(c) Copyright: The Author(s)

This is an Open Access article distributed under the terms of the Creative Commons Attribution Non-Commercial License (https://creativecommons.org/licenses/by-nc/4.0/) which permits unrestricted non-commercial use, distribution, and reproduction in any medium, provided the original work is properly cited. performance are stimulated, enlivened, guided, and preserved through the motivation system that drives individuals to take actions intended for attaining a craving goal (Alajmi \& Alasousi, 2019). Motivation has been one of the significant and determining factors that essentially regulates influencing action and performance in humans. The workforce was believed to be one of the resources that upgrade the production process of services and products in the past. Nonetheless, in this regard, a lot of transformation is being witnessed currently. All business organizations ought to take the crucial step of motivating the workforce of the organization (Abdullah \& Islam, 2012) because motivation is the factor that inspires the organization workforce to perform better and remain more productive. When the workforce is motivated, employees become the fundament and most important asset for every organization since motivation is a principal driver for an individual as well as for organizations to perform better. This applies in every sector, private and public, and non-profit organizations. Therefore, motivation has become a salient matter of sustained consideration for academics, researchers, business managers and consultants (Anderfuhren-Biget et al., 2010). 
In the literature, the noteworthy influence that the workforce's motivation has on productivity of organization, and dedication and engagement of employees, has been recorded to a great extent (Babalola \& Nwalo, 2013). An organization's management can contribute to the academic foundation that introduces change and starts development through recognizing the aspects that play a part in individual behavior. Examining and recognizing the motivating variables of employee's behavior would provide a business firm's managerial board with a conceptual foundation on how to commence a transformation within the organization. Specifically, earlier studies conducted on motivation were intended to emphasize the driving factors of motivation as an appropriate engine for human behavior (Ellemers et al., 2004). The answers produced by these studies support the concept that every behavior relating to a single person is affected by important determinants that originate from the objectivized actions. A pivotal part of a motivating workforce is to bring enhanced organizational outcomes and increased business performance (Bowen \& Radhakrishna, 1991).

Once the workforce feels motivated, it will sense contentment in the work, and will work more devotedly, which would consequently result in making their performances more efficient (Pancasila et al., 2020). Motivation itself is an aim or result an individual is trying to achieve as well as a method that helps the workforce to finish its work in an efficient and productive manner. When the entire workforce is well aware of the standard, morals, obligations, and goals of the organization, it does reflect strongly on the company (Nguyen et al., 2020). A considerable academic literature has sought to respond to the question: What does motivate the employees? Hence, it has become indispensable for the business managers to discover methods through which selfesteem and satisfaction level of employees can be ameliorated.

Why is an organization in need of motivated workforce? The answer to this question goes to the essence of the organization's existence. Employees who are motivated to a high degree are required in today's dynamic workplace environment. Motivated workforce unceasingly contributes to the organizational flourishment and survival because a motivated workforce helps enhance organizational productivity and enables an organization to attain greater level of production (Do et al., 2020). Still, motivating the workforce is possibly the most intricate and entangled matter that the business managers are encountering in recent times. Bangladesh has been treated across the world as a country with economic potential because of growing economic activities, which lead to an increased economic growth (Rahaman et al., 2020; Akhter et al., 2020; Hossain et al., 2019).

In Bangladesh's economic growth, not only small- and medium-sized enterprises have contributed (Hossain \& Asheq, 2019), but also service organizations have played a crucial role in the country's development. To keep this momentum, it is essential for the business and service organizations to retain their employees and keep them motivated at the workplace, as employees are considered as the most important component of any business firm (Hanaysha \& Majid, 2018). If employees remain dissatisfied and demotivated in the service industry, then business performance might face a decline in future. Therefore, it is a timely requirement for service organizations to keep track of the factors that would motivate their service employees in Bangladesh's context. Hence, the current study seeks to examine and find out the motivating factors that would affect service employees' motivation in Bangladesh.

\section{Literature Review}

\subsection{Motivation}

The word 'motivation' originates from the Latin word "movere", which means to cause change in position (Islam \& Ismail, 2008). Motivation takes us from the state of feeling bored to having a feeling of interest. Motivation is explained as an inner energy that puts behavior into action and provides a guidance. The theories of motivation are relevant to the approaches that provide an explanation of why an individual's behavior is put into action (Amzat et al., 2017). Motivation is described as what individuals yearn to accomplish; the stimulus and the term motivation identify the wants, desires, and a hope of achieving something within individuals, which lead them to act as they do presently (Walker \& Miller, 2009). It has been considered as one of the most significant areas of research on human resources and organization's studies. A great number of scholars have also described the idea of motivation. For instance, motivation can be regarded as the procedure relating to the inner mind and mental activity that provides behavioral motive and guidance (Kreitner, 1995) and a determination that comes from the inner self to fulfill needs and wants that are yet to be met (Higgins, 1994). It is referred to as a method of invigorating individuals to act and attain an intended mission. An awareness and knowledge of the variables that ultimately energize the workforce might be supportive for the managers to determine job assignments and reward system for encouragement purpose. Therefore, organizations can utilize motivating factors as a set of managerial strategies (Sulaiman et al., 2014).

\subsection{Theories on Motivation}

Some theories on motivation developed from the last 50 years are so long-lasting that they are pragmatically applicable to resolve ongoing organizational problems. Herzberg et al.'s (1959) two-factor theory keeps on examining the behaviors of dissatisfied people in their working environment. Herzberg's (2008) theory identified and highlighted a significant division in the elements 
that motivate employees; the elements that meet the expectation, and consequently stimulate, are intrinsic variables (satisfiers), namely, the opportunities for career advancement and growth, moderated through the existence of extrinsic variables (hygiene factors), namely, salary and working environment. The satisfiers and motivators will have little or no influence if the hygiene factors are inadequate, as the workforce will be incapable of valuing the intrinsic benefits of their work at the same time as being bothered by conditional issues that need to be resolved. Another notable motivation-related theory is postulated by Abraham Maslow (Maslow, 1943), coined as Maslow's hierarchical needs theory. The hierarchy comprises five stages of human needs that have to be satisfied sequentially.

Alderfer (1972) puts forward for consideration a theory known as ERG theory, which is an alternative to Maslow's motivational proposition. Alderfer (1972) transformed Maslow's hierarchical five stages into three stages: existence $(\mathrm{E})$, relatedness $(\mathrm{R})$, and growth $(\mathrm{G})$. Existence generally incorporates physiological variables, namely, food, accommodation, clothing, substantial salary, additional benefits, and healthy working conditions, whereas relatedness focuses on human interactive bonding with other people in society, for instance, families, companions, and social groups. Growth has been tied with the last two stages of Maslow's theory, which are self-esteem and selfactualization. Vroom's expectancy theory is originally founded on the basis that the effort of the workforce will result in performance, and sequentially better workforce performance will generate rewards (Vroom, 1964). Rewards can take one of two forms: positive or negative. The likelihood of the workforce being exceedingly motivated is higher if the reward is more positive; in contrast, the likelihood of the workforce being motivated is lower if the reward is negative.

\subsection{Employees' Motivational Factors}

The attainment of employee motivation is possible through numerous variables that would facilitate workforce motivation, and the motivation would necessarily influence employee's productivity, which would drive organizational performance. Flynn (2011) emphasized that both business managers and recruiters have been involved in the game of motivation at the workplace, where financial payment is the utmost significant motivational variable for employees to elevate their work performance in office; the other set of variables comprises organizational connection, working atmosphere, employee's desire, safety, fairness, opportunity for career growth, and fair monitoring mechanism. These motivating variables will stimulate the morale of employees and improve their performance. In respect of the workforce's motivating variables Cruz et al. (2009) have postulated the motivational variables through advancing the concept of both intrinsic and extrinsic motivation. Intrinsic motivation rewards consist of an individual's gained contentment from his or her own placement, while extrinsic motivation rewards relates with regular workplace-related factors, which the employees anticipate at their workplace.

Cruz et al. (2009) referred to intrinsic motivation rewards as a set of factors, which are self-assurance, independence, trustworthiness and association, and the extrinsic motivational elements include high-power inducements, gratitude, advancement, and steadiness. Malik (2010) conducted a research inquiry that examined thoroughly the ranked significance of employee motivational factors at the workforce of Serbian university, and he found that safe and protected working environment with good remuneration are pivotal in creating greater level of workforce motivation. Mani (2002) interviewed four categories of professionals working at East Carolina University in order to gauge their motivation and found that decent salary and acknowledgement from management were the most important variables that would motivate them. Kubo and Saka (2002) showed that financial stimulus, skill development, and independence at the workplace acted as motivators for the knowledge employees in the financial sector in Japan. The study by Sewell and Gilbert (2015) revealed that individual achievement, interaction with colleagues and new opportunities are the crucial motivating factors for the service employees.

\section{Methodology}

The research study applied convenience sampling approach in order to identify the service employee's motivational aspects at the various service organizations in Bangladesh. In this research, structured survey questionnaire is used for data collection purpose, which consists of a checklist of ten purposeful motivating factors, and the respondents are requested to rank the motivating factors based on the importance of those factors, followed by their perceptions. In the ranking process, a 1-to-10 scale is used, in which ' 1 ' denotes the most significant motivating factor and ' 10 ' denotes the least significant motivating factor. Respondents are also requested to use only ranked number for one motivating factor to avoid ranking duplication. These purposeful motivating factors have been mainly adopted from Kovach (1980), Kovach (1987) and Islam and Ismail (2008), which are as follows:

1. Job certainty and safety

2. Career growth and advancement at workplace

3. Quality working environment

4. Satisfactory remuneration and salary package

5. Fascinating and exciting job

6. Acknowledgement and admiration of work done 
7. Job responsibility

8. Fair and reasonable organizational rules and policies

9. Managerial assistance to resolve problems

10. Opportunity to develop new job skills

The questionnaire comprises two parts: the first part includes the demographic information such as age, gender, marital status, and the second part includes the set of above-mentioned ten motivating factors. Some 240 survey questionnaires were distributed among the employees of various service organizations and 183 valid responses were received (77\% response rate). For data analysis purpose, SPSS is used to identify which factors are more motivating for service employees in Bangladesh. The lowest mean value of the motivating factors is considered as the most significant motivating factor.

\section{Results and Discussion}

Table 1 describes the demographic profile of the respondents in the study. The total sample size of this study is 183 , in which 134 respondents are male $(73.2 \%)$ and 49 respondents are female (26.8\%). In terms of age distribution, $36-40$ year old and 41-45 year old groups account each for $13.1 \% ; 4.4 \%$ of the respondents are below 20 ; and $31.7 \%$ are in the 31-35 age group. 139 employees are married (76\%) and 44 employees are single (24\%). In terms of length of service, only 25 employees have been in their job for less that one year $(13.7 \%), 61$ employees have been in the job for 1-3 years (33.3\%), 50 employees have been working for 4-7 years $(27.3 \%), 27$ employees have been working for 8-10 years $(14.8 \%)$ and 20 employees have been doing their job for more than 10 years at the organizations $(10.9 \%)$.

Table 1: Demographic information of the respondents

\begin{tabular}{|l|c|c|}
\hline & Frequency & Percent \\
\hline Gender & & 73.2 \\
\hline Male & 134 & 26.8 \\
\hline Female & 49 & \\
\hline & & 4.4 \\
\hline Age & & 7.7 \\
\hline 20 years or below & 8 & 23.5 \\
\hline $21-25$ years & 14 & 31.7 \\
\hline $26-30$ years & 43 & 13.1 \\
\hline $31-35$ years & 58 & 13.1 \\
\hline $36-40$ years & 24 & 6.6 \\
\hline $41-50$ years & 24 & 24.0 \\
\hline more than 50 years & 12 & 76.0 \\
\hline & & \\
\hline Marital Status & & 14.8 \\
\hline Single & 139 & 13.7 \\
\hline Married & & 33.3 \\
\hline & & 27.3 \\
\hline Length of doing the service & 25 & 10.9 \\
\hline less than 1 years & 61 & \\
\hline $1-3$ years & 50 & \\
\hline $4-7$ years & 27 & \\
\hline $8-10$ years & 20 & \\
\hline more than 10 years & & \\
\hline (n=183) & & \\
\hline
\end{tabular}


Table 2: Overall ranking of the motivating factors

\begin{tabular}{|l|c|c|c|}
\hline Factors that motivate employees & $\boldsymbol{n}$ & Mean & Rank \\
\hline Job certainty and safety & 183 & 2.78 & 1 \\
\hline Career progression and advancement at workplace & 183 & 3.66 & 2 \\
\hline Quality working environment & 183 & 3.92 & 3 \\
\hline Satisfactory remuneration and salary package & 183 & 3.95 & 4 \\
\hline Fascinating and exciting job & 183 & 5.49 & 5 \\
\hline Managerial assistance to resolve problems & 183 & 6.62 & 8 \\
\hline Acknowledgement and admiration of work done & 183 & 6.34 & 6 \\
\hline Fair and reasonable organizational rules and policies & 183 & 7.63 & 10 \\
\hline Job responsibility & 183 & 6.44 & 7 \\
\hline Opportunity to develop new job skills & 183 & 7.37 & 9 \\
\hline
\end{tabular}

Table 3: Ranking of the motivating factors between male and female service employees

\begin{tabular}{|l|c|c|c|c|c|c|}
\hline \multirow{2}{*}{ Factors that motivate employees } & \multicolumn{3}{|c|}{ Male Employee } & \multicolumn{3}{c|}{ Female Employee } \\
\cline { 2 - 7 } & $\boldsymbol{n}$ & Mean & Rank & $\boldsymbol{n}$ & Mean & Rank \\
\hline Job certainty and safety & 134 & 2.81 & 1 & 49 & 2.67 & 1 \\
\hline Career progression and advancement at workplace & 134 & 3.77 & 3 & 49 & 3.37 & 2 \\
\hline Quality working environment & 134 & 3.70 & 2 & 49 & 4.51 & 4 \\
\hline Satisfactory remuneration and salary package & 134 & 3.81 & 4 & 49 & 4.33 & 3 \\
\hline Fascinating and exciting job & 134 & 5.30 & 5 & 49 & 6.00 & 5 \\
\hline Managerial assistance to resolve problems & 134 & 6.75 & 8 & 49 & 6.29 & 8 \\
\hline Acknowledgement and admiration of work done & 134 & 6.40 & 6 & 49 & 6.18 & 6 \\
\hline Fair and reasonable organizational rules and policies & 134 & 7.67 & 10 & 49 & 7.53 & 10 \\
\hline Job responsibility & 134 & 6.51 & 7 & 49 & 6.27 & 7 \\
\hline Opportunity to develop new job skills & 134 & 7.60 & 9 & 49 & 6.71 & 9 \\
\hline
\end{tabular}

Table 2 explains the most significant factors that motivate the service employees regardless of gender dimension. In this table, it can be seen that 'job certainty and safety' $(\mu=2.78)$ has been ranked as the most crucial motivating variable; the second most crucial motivating variable is 'career progression and advancement at workplace' $(\mu=3.66)$; the third most significant motivating factor is 'quality working environment' $(\mu=3.92)$; and the least important motivating factor is 'fair and reasonable organizational rules and policies' $(\mu=7.63)$.

Table 3 shows male and female employees' perceived ranking of the motivating factors at the workplace. Again 'job certainty and safety' has been ranked as the most important factors by both male and female employees. 'Quality working environment' is ranked as second most critical motivating factor by male employees $(\mu=3.77)$, while female employees rank 'career progression and advancement at workplace' as the second most crucial factor $(\mu=3.37)$. In contrast, 'fair and reasonable organizational rules and policies' has been ranked as the least motivating factor by both male and female employees.

\section{Conclusions}

The findings of the research show that not, only financial benefit, but also non-financial benefits have been critical for both male and female service employees. In order to energize and motivate the workforce regardless of background, job certainty, better working environment, competitive salary package and other relevant fringe benefits are essential to be incorporate into the organization's policy according to the performance of the respective employees. Nonetheless, the findings of the study might be not be sufficient to deal with the motivational issues unless the respective service business organizations adopt essential initiatives to meet employees' wants and needs. In this case, employees' engagement and their feedback can be critical in formulating a practical motivational program. 


\section{References}

Abdullah, M. M. B., \& Islam, R. (2012). Employee motivational factors: a comparison between Malaysia and Sultanate of Oman. Journal for Global Business Advancement, 5(4), 285-306.

Akhter, A., Hossain, M. U. \& Asheq, A. A. (2020). Influential Factors of Social Entrepreneurial Intention in Bangladesh. Journal of Asian Finance, Economics and Business, 7(8), 645-651.

Alderfer, C.P. (1972). Existence, Relatedness, and Growth: Human Needs in Organizational Settings. New York, NY: Free Press.

Amzat, I. H., Don, Y., Fauzee, S. O., Hussin, F., \& Raman, A. (2017). Determining motivators and hygiene factors among excellent teachers in Malaysia. International Journal of Educational Management. 31(2), 78-97.

Alajmi, B., \& Alasousi, H. (2019). Understanding and motivating academic library employees: theoretical implications. Library Management. 40(3/4), 203-214.

Anderfuhren-Biget, S., Varone, F., Giauque, D., \& Ritz, A. (2010). Motivating employees of the public sector: does public service motivation matter?. International Public Management Journal, 13(3), 213-246.

Babalola, G. A., \& Nwalo, D. R. K. I. N. (2013). Influence of job motivation on the productivity of librarians in colleges of education in Nigeria. Commitment, 3(5), 70-75.

Bowen, B. E., \& Radhakrishna, R. B. (1991). Job satisfaction of agricultural education faculty: A constant phenomena. Journal of Agricultural Education, 32(2), 16-22.

Cruz, N.M., Pérez, V.M. \& Cantero, C.T. (2009). The influence of employee motivation on knowledge transfer. Journal of Knowledge Management, 13(6), 478-490.

Do, A. D., Pham, N. T., Bui, H. P., Vu, D. T., Nguyen, T. K., \& Nguyen, T. H. (2020). Impact of Motivational Factors on the Work Results of Lecturers at Vietnam National University, Hanoi. Journal of Asian Finance, Economics and Business, 7(8), 425-433. https://doi.org/10.13106/jafeb.2020.vol7.no8.425

Ellemers, N., De Gilder, D., \& Haslam, S. A. (2004). Motivating individuals and groups at work: A social identity perspective on leadership and group performance. Academy of Management Review, 29(3), 459-478.

Flynn, S. (2011). Can you directly motivate employees? Exploding the myth. Development and Learning in Organizations, 25(1), 11-15.

Hanaysha, J. R., \& Majid, M. (2018). Employee motivation and its role in improving the productivity and organizational commitment at higher education institutions. Journal of Entrepreneurship and Business, 6(1), 17-28.

Herzberg, F. (2008). One more time: how do you motivate employees. Boston, MA: Harvard Business Review.
Herzberg, F., Maunser, B. \& Synderman, B. (1959). The Motivation to Work. New York, NY: John Wiley,

Higgins, J.M. (1994) The Management Challenge: an introduction to management $\left(2^{\text {nd }}\right.$ ed.). New York, NY: Macmillan.

Hossain, M.U., Asheq, A. A. \& Arifuzzaman, S. M. (2019). Entrepreneurial intention of Bangladeshi students: impact of individual and contextual factors. Problems and Perspectives in Management, 17(4), 493-503.

Hossain, M. U., \& Asheq, A. A. (2019). The Role of Entrepreneurial Orientation to SME Performance in Bangladesh. International Journal of Entrepreneurship, 23(1), 1-6.

Islam, R., \& Ismail, A. Z. H. (2008). Employee motivation: a Malaysian perspective. International Journal of Commerce and Management. 18(4), 344-362.

Kovach, K. A. (1987). What motivates employees? Workers and supervisors give different answers. Business Horizons, 30(5), 58-65.

Kovach, K. A. (1980). Why motivational theories don't work. SAM Advanced Management Journal, 45(2), 54-59.

Kreitner, R. (1995) Management, $6^{\text {th }}$ edition. Boston, MA: Houghton Mifflin Company.

Kubo, I., \& Saka, A. (2002). An inquiry into the motivations of knowledge workers in the Japanese financial industry. Journal of Knowledge Management, 6(3), 262-271.

Malik, N. (2010). A study on motivational factors of the faculty members at University of Balochistan. Serbian Journal of Management, 5(1), 143-149.

Mani, B. G. (2002). Performance appraisal systems, productivity, and motivation: A case study. Public Personnel Management, 31(2), 141-159.

Maslow, A.H. (1943). A theory of human motivation. Psychological Review, 50(5), 370-396.

Nguyen, H. N., Le, Q. H., Tran, Q. B., Tran, T. H. M., Nguyen, T. H. Y., \& Nguyen, T. T. Q. (2020). The Impact of Organizational Commitment on Employee Motivation: A Study in Vietnamese Enterprises. Journal of Asian Finance, Economics and Business, 7(6), 439-447. https://doi.org/10.13106/jafeb.2020. vol7.no6.439

Pancasila, I., Haryono, S., \& Sulistyo, B. A. (2020). Effects of Work Motivation and Leadership toward Work Satisfaction and Employee Performance: Evidence from Indonesia. Journal of Asian Finance, Economics and Business, 7(6), 387-397. https://doi.org/10.13106/ jafeb.2020.vol7.no6.387

Rahaman, M. A., Ali, M. J., Mamoon, Z. R., \& Asheq, A. A. (2020). Understanding the Entrepreneurial Intention in the Light of Contextual Factors: Gender Analysis. Journal of Asian Finance, Economics and Business, 7(9), 639-647. https://doi. org/10.13106/jafeb.2020.vol7.no9.639 
Sewell, B. B., \& Gilbert, C. (2015). What makes access services staff happy? A job satisfaction survey. Journal of Access Services, 12(3/4), 47-74.

Sulaiman, M., Ahmad, K., BaraaSbaih, B. \& Kamil, M.N. (2014). The perspective of Muslim employees towards motivation and career success. Journal of Social Sciences and Humanities, 9(1), 45-62.
Vroom, V.H. (1964). Work and Motivation. Hoboken, NJ: John Wiley.

Walker, J. R., \& Miller, J. E. (2009). Supervision in the hospitality industry: Leading human resources. Hoboken, NJ: John Wiley and Sons. 